\title{
Mitigation of magnetising inrush current in three-phase power transformer
}

\author{
Mudita Banerjee, Anita Khosla \\ Department of Electrical and Electronics Engineering, Manav Rachna International Institute of Research and Studies, India
}

\begin{tabular}{|c|c|}
\hline Article Info & ABSTRACT \\
\hline Article history: & \multirow{11}{*}{$\begin{array}{l}\text { During energization of no-load transformers, a high and peaky current flow } \\
\text { on the primary side which has rich second harmonics. This current is } \\
\text { magnetising inrush current and it is generated when transformer core is } \\
\text { driven deep into saturation. This current has various disturbances on } \\
\text { transformer attribute; reduced life-span, major voltage drop, insulation } \\
\text { weakening, electrical and mechanical vibrations in coils, difficulties in } \\
\text { protecting relays and all leads to poor power quality of the electric system. } \\
\text { This paper presents the analysis and comparison of recent techniques to } \\
\text { reduce the magnitude of inrush current during energization of power } \\
\text { transformer. The simulation results are provided for Pre-insertion of resistors, } \\
\text { Controlled swithing and Pre-fluxing method. The best method is suggested } \\
\text { for mitigating inrush current by simulating in MATLAB/SIMULINK environment. } \\
\text { Copyright } \odot 2020 \text { Institute of Advanced Engineering and Science. } \\
\text { All rights reserved. }\end{array}$} \\
\hline Received Jan 27, 2020 & \\
\hline Revised Mar 29, 2020 & \\
\hline Accepted Apr 13, 2020 & \\
\hline Keywords: & \\
\hline Controlled switching & \\
\hline Inrush current & \\
\hline Power transformer & \\
\hline Pre-fluxing & \\
\hline Pre-insertion resistor & \\
\hline Residual flux & \\
\hline
\end{tabular}

Corresponding Author:

Mudita Banerjee,

Department of Electrical and Electronics Engineering,

Manav Rachna International Institute of Research and Studies, Haryana, India.

Email: mmmudita@gmail.com

\section{INTRODUCTION}

With rise in technology and industrialization, there is a requirement for an uninterrupted power supply. Further, it needs flawless operation of an electrical system. Single-phase and three-phase power transformers are essential devices and hence, they need special protection and maintenance. The differential protection relay, which is the conventional protection system in large transformers, mal-operates during magnetizing inrush condition. M. Steurer inspected the effect of inrush currents on the transformer windings and his results show that the $70 \%$ peaks of inrush current causes same impact as that of short circuit [1]. Magnetizing currents appear during the energization of power transformer due to its core magnetization and saturation. This core draws a very large current, about 3 to 7 times the rated current. The expression for flux just after switching can be written as in (1).

$$
\phi=\phi_{R}+\phi_{m} \cos \theta-\phi_{m} \cos (\omega t+\theta)
$$

Thus, flux in the transformer is a function of the residual flux, instant of switching, magnetic properties of core. This current has various disturbances on transformer attribute: reduced life-span, major voltage drop, insulation weakening, electrical and mechanical vibrations in coils, difficulties in protecting relays and all leads to poor power quality of the electric system [2-5]. Many inrush current mitigation techniques have been proposed over the years each with its own advantages and disadvantages. From the past few years, research is going on to mitigate this current [6-16]. Controlled switching in transformer can possibly remove these transients if residual core is considered in the closing process [17-18]. Another researcher, Yu Chi had proposed a method wherein a grounding resistor is connected to the neutral point of transformer. Their results show that after energizing each phase sequencially, the behaviour of 
neutral resistor is like a series-inserted resistor and it decreases magnitude of inrush currents [19-20]. Inrush current in power transformers can be controlled by applying long pulses. This is because current lags the voltage wave. The inrush current reduces as the firing angle increases. The magnitude of these currents is low at 90 degrees [21-22]. This paper presents the analysis and comparision of recent techniques: Pre-insertion resistor; Controlled switching and Pre-fluxing method, to reduce the magnitude of inrush current. The simulation results are provided in MATLAB/SIMULINK environment.

\section{SIMULATION OF POWER SYSTEM}

This section describes the simulation of magnetizing inrush current in a saturable core transformer. The simulation of the system is performed in MATLAB. The parameters of the power transformer considered in this paper is given in Table 1 . This 50 MVA, 220/66kV power transformer is connected to the three-phase source through a three-phase circuit breaker. The block diagram of the simulated model is shown in Figure 1 with NoLoad condition. Figure 2 shows the magnetizing inrush current for phase ' $\mathrm{R}$ ' which is simulated for 1 second.

Table 1. Power transformer parameters

\begin{tabular}{llll}
\hline Nominal power and frequency & \multicolumn{3}{c}{$\mathrm{S}=50 \mathrm{MVA} ; \mathrm{f}=50 \mathrm{~Hz}$} \\
\hline Primary winding parameters & $\mathrm{V} 1=220 \mathrm{kV}$ & $\mathrm{R} 1=0.02$ & $\mathrm{~L} 1=0.08$ \\
Secondary winding parameters & $\mathrm{V} 2=66 \mathrm{kV}$ & $\mathrm{R} 2=0.02$ & $\mathrm{~L} 2=0.08$ \\
Core loss resistance & $\mathrm{R}_{\mathrm{m}}=500 \Omega$ & & \\
\hline
\end{tabular}

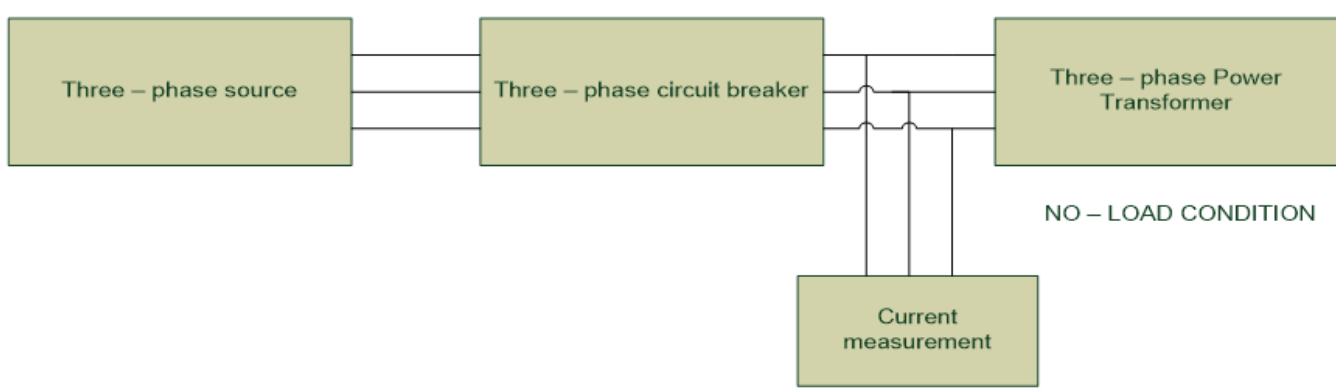

Figure 1. Simulink model for Inrush current without mitigation

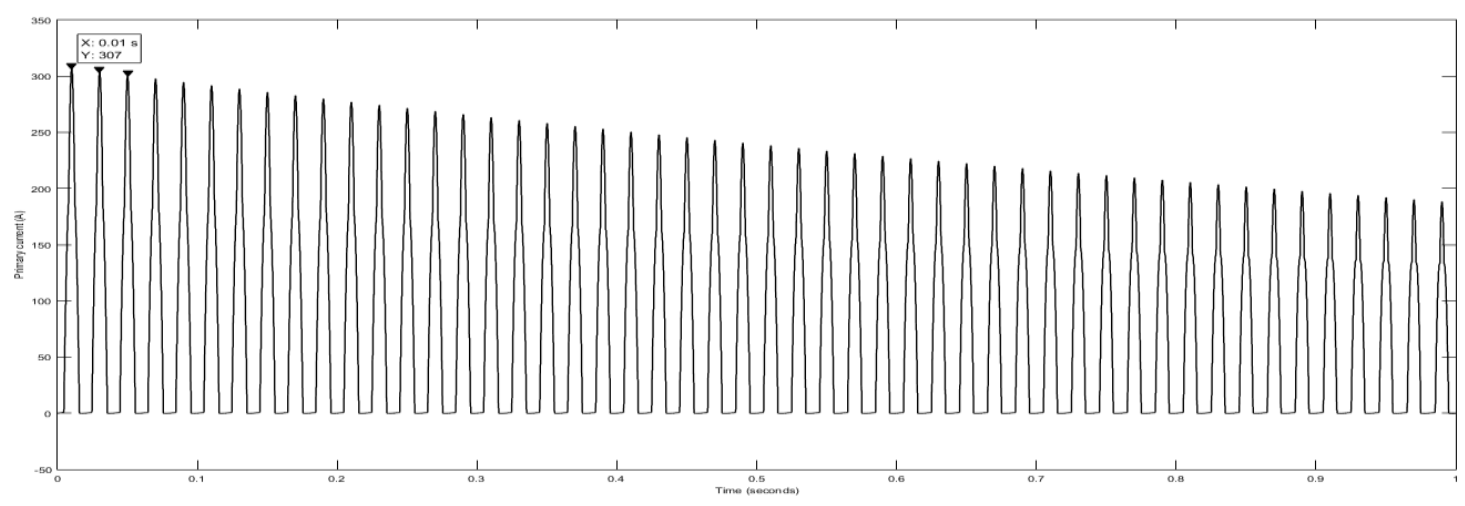

Figure 2. Magnetizing inrush current of 50 MVA transformer

The magnitude of inrush current is $307 \mathrm{~A}$ at the first peak, which is about 3 times the rated current. And after 1 second, it comes up to around 200 A. There is a DC component present in inrush current waveform and is rich in second harmonics [2]. The presence of DC component slows down the response of protection system and generally deteriorates the discrimination ability of the relay. Figure 3 shows the normal current at the primary side of the transformer when it is on no-load condition. Inrush current mitigation techniques presented in this paper are Pre-insertion resistor, Controlled switching and Pre-fluxing. The effect of application of these techniques on the magnitude of inrush current can be seen in the next sub-sections. 


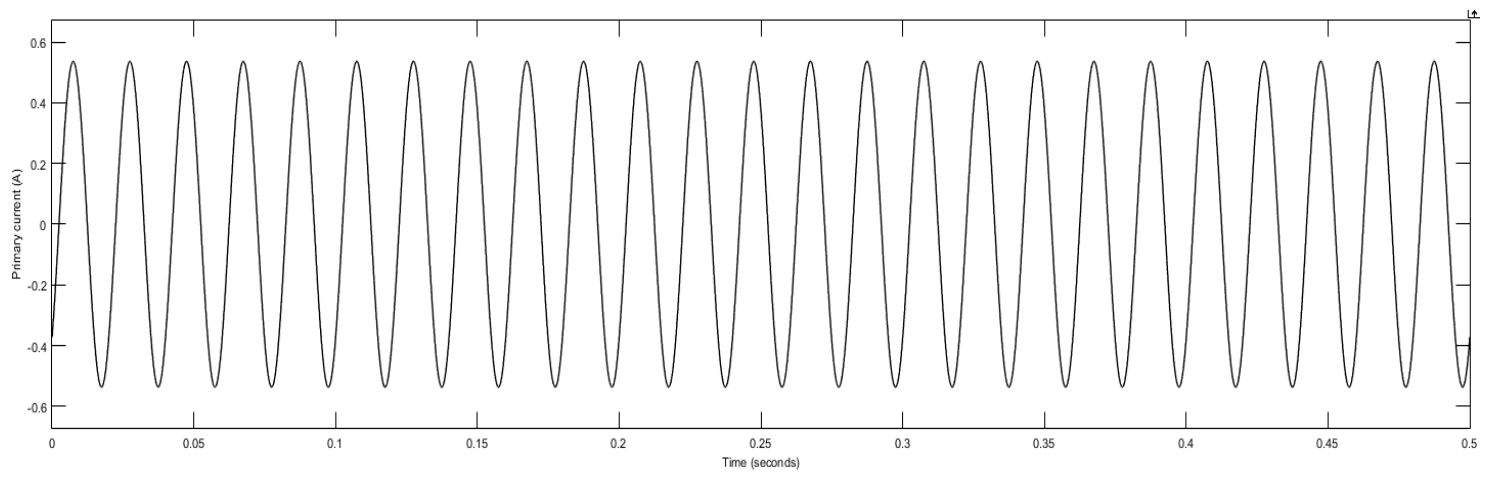

Figure 3. Line-to-line normal primary current

\subsection{Effect of pre-insertion resistor}

The inrush current can be reduced by inserting the optimum value of resistance at the primary side of the transformer. Table 2 demonstrates the magnitude of inrush current for various resistance taken between zero to $425 \Omega$. Figure 4 shows the graph of inrush current value at various values of resistor. The results direct the best value of resistance as $382 \Omega$ with a minimum insertion time of $10 \mathrm{msec}$ that will eliminate transient during energization. The waveform is shown in Figure 5. The magnitude of inrush current decreases to the rated current of 131A. The magnitude of inrush current is decreasing between $350 \Omega$ to $400 \Omega$ resistance and mitigate at an optimum value of $382 \Omega$ as cited in Table 3.

Table 2. Inrush current magnitude for different values of resistors

\begin{tabular}{cccc}
\hline External Resistance $(\Omega)$ & Phase R Current $(\mathrm{A})$ & Phase Y Current $(\mathrm{A})$ & Phase B Current $(\mathrm{A})$ \\
\hline 0 & 307.20 & -192.36 & -192.23 \\
50 & 269.80 & -177.35 & -167.91 \\
100 & 237.42 & -167.00 & -148.12 \\
150 & 211.38 & -157.24 & -132.60 \\
200 & 187.77 & -148.76 & -119.81 \\
225 & 179.71 & -144.55 & -115.19 \\
250 & 171.07 & -140.93 & -110.66 \\
275 & 162.74 & -137.42 & -106.53 \\
300 & 155.21 & -134.02 & -102.74 \\
325 & 146.94 & -130.73 & -98.95 \\
350 & 139.72 & -126.08 & -95.44 \\
375 & 132.94 & -124.00 & -92.95 \\
400 & 123.15 & -118.03 & -89.10 \\
425 & 117.02 & -114.77 & -86.25 \\
\hline
\end{tabular}

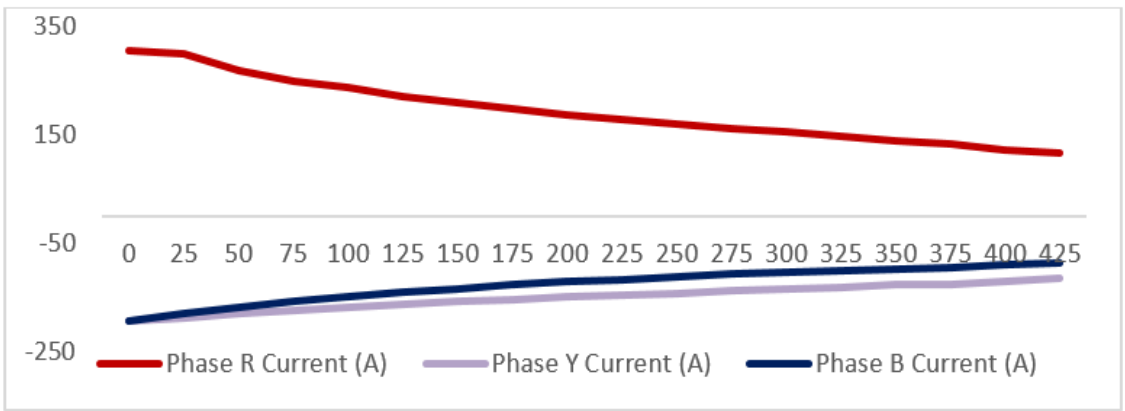

Figure 4. Graph showing inrush current value at various values of resistor

Table 3. Inrush current for $\mathrm{R}=382 \Omega$

\begin{tabular}{cccc}
\hline Optimum resistance $(\Omega)$ & \multicolumn{3}{c}{ Inrush current (A) } \\
& Phase R Current (A) & Phase Y Current (A) & Phase B Current (A) \\
\hline 382 & 131.11 & -123.60 & -92.14 \\
\hline
\end{tabular}



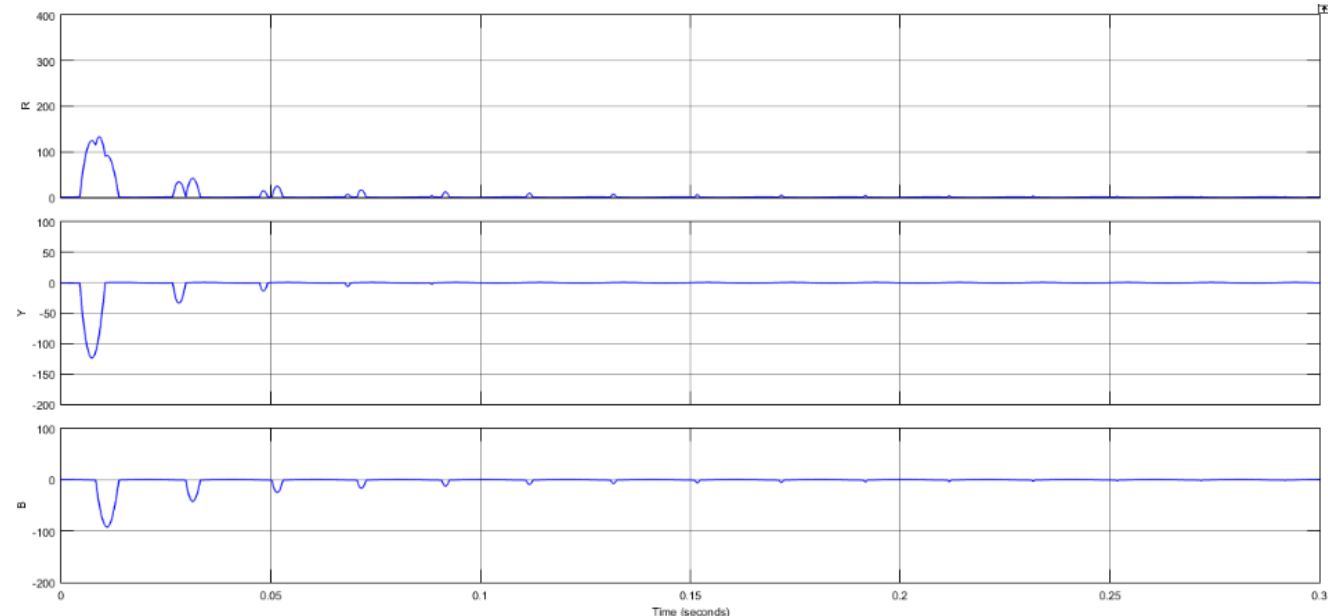

Figure 5. Inrush current in three phases with pre-insertion resistor technique $(\mathrm{R}=382 \Omega)$

\subsection{Effect of controlled switching}

All three-phase systems have a 120 electrical degree phase shift between each phase. A standard three-phase circuit breaker switches all three phases at the same time. With controlled switching, the phases are independently operated at the most favourable time instant for minimizing electrical transients [23].

The benefits of Controlled switching are:

a. Better power quality-Lower inrush currents; lower voltage transients

b. longer service intervals for the circuit breaker

c. reduced electrical stress on substation equipment [24].

In this method, three single-phase circuit breakers are connected on each phase and are operated one after the other with 120 electrical degree phase shift. The value of inrush current at different switching instants is given in Table 4. The resultant waveforms are shown in Figure 6.

Table 4. Value of inrush current at different firing angles

\begin{tabular}{cccc}
\hline Firing angle (Degree) & Phase R Current (A) & Phase Y Current (A) & Phase B Current (A) \\
\hline 0 & 134.0 & 56.3 & 134.4 \\
30 & 157.5 & 61.8 & 158.0 \\
60 & 120.5 & 67.8 & 120.8 \\
$\mathbf{9 0}$ & $\mathbf{3 9 . 2}$ & $\mathbf{4 0}$ & $\mathbf{3 3}$ \\
180 & 150 & 53.1 & 150 \\
\hline
\end{tabular}
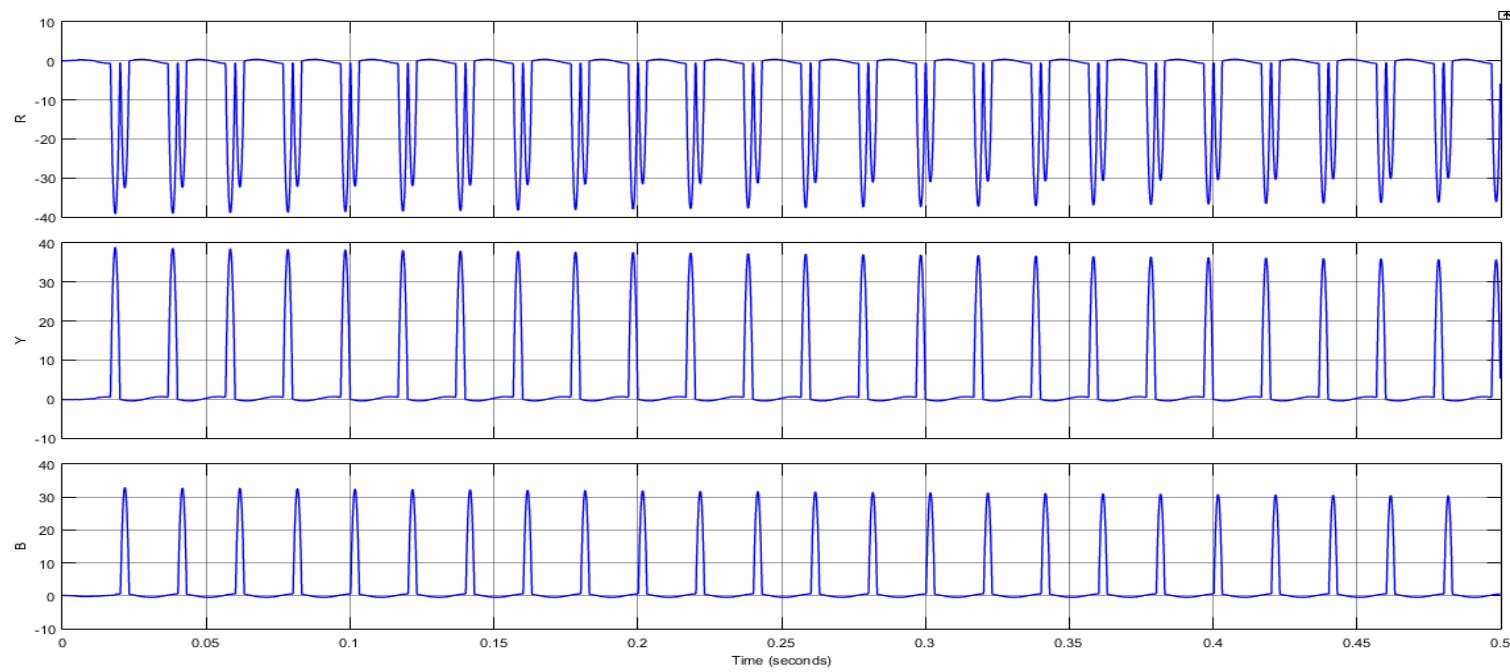

Figure 6. Inrush current in three phases with controlled switching technique 


\subsection{Effect of pre-fluxing method:}

In pre-fluxing method, to reduce the magnitude of inrush current, pre-fluxing device is used [25]. This device consists of a capacitor, which is charged to a user specified voltage and discharged into the transformer. During the discharging period, circuit breaker should be closed. To reduce the inrush current magnitude, the residual flux of the transformer must be high. Figures 7 and 8 shows the pre-fluxing device and its connection at the primary side of the three-phase power transformer. Figure 9 shows the resulted reduced inrush current with magnitude of 32.62A. The filter connected in the primary side blocks the harmonics present in inrush current. This resultant current is free from DC component also which delays the response of protection system and causes mal-operation of relay.

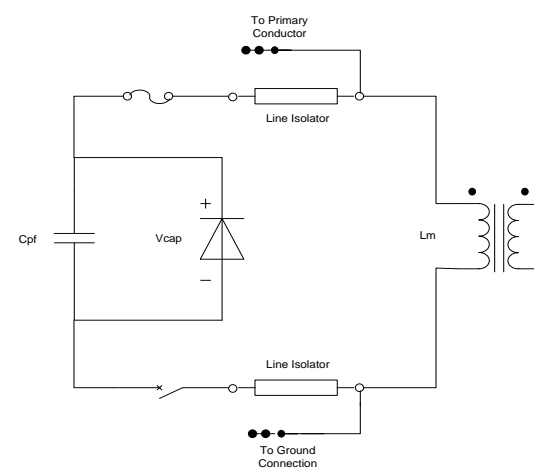

Figure 7. Pre fluxing device

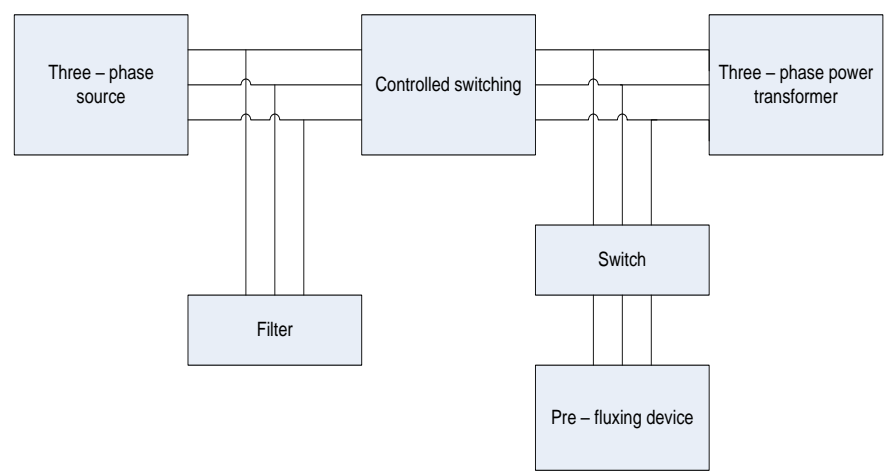

Figure 8. Pre-fluxing device at primary of power transformer

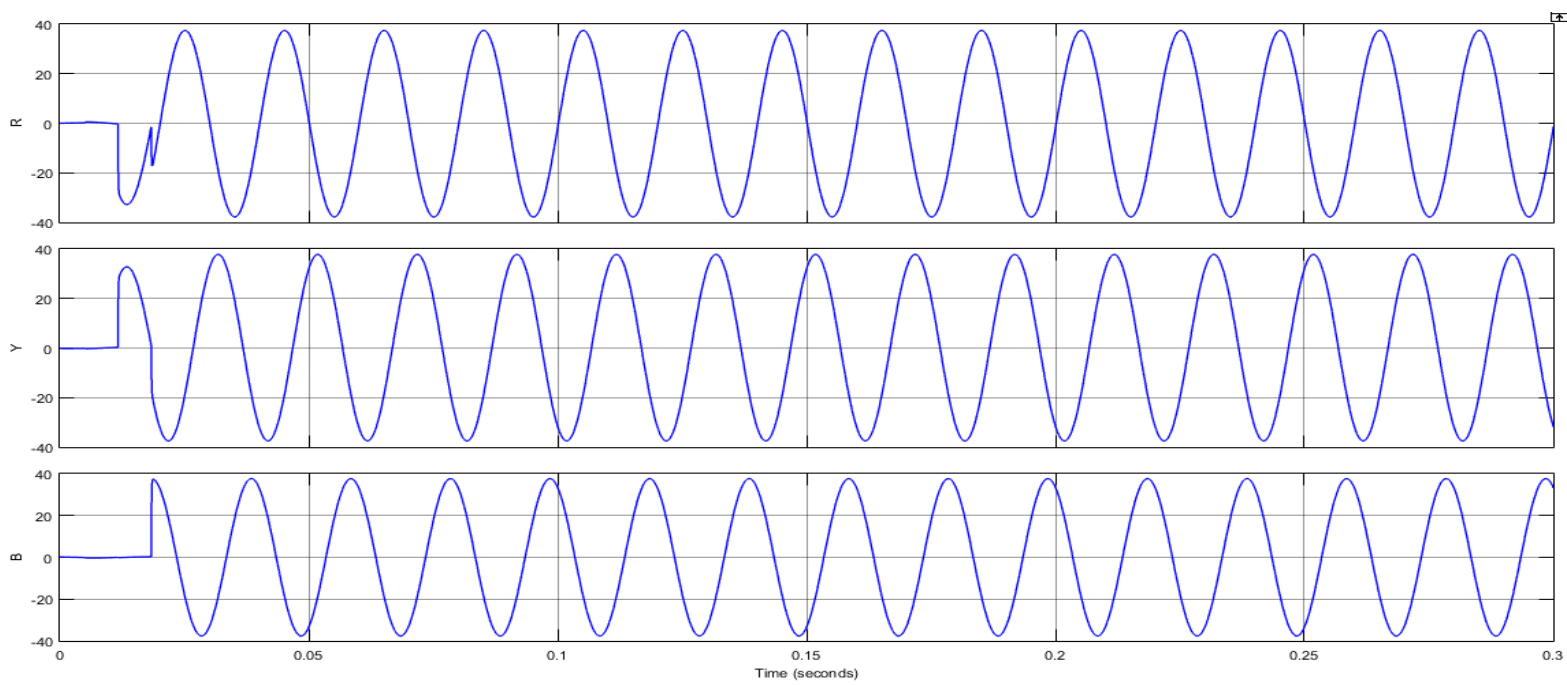

Figure 9. Mitigated inrush current in phase three phases

\section{RESULTS}

Table 5 shows the comparision among the three techniques presented in this paper. Result shows that both the controlled switching and pre-fluxing method have reduced the magnitude of inrush current. But with pre-fluxing method, the DC component is also gets eliminated.

Table 5. Comparision among different methods

\begin{tabular}{cccc}
\hline Mitigation methods & R-phase (A) & Y-phase (A) & B-phase (A) \\
\hline Pre-insertion Resistor & 131.11 & 123.6 & 96.17 \\
Controlled switching & 39.20 & 40.00 & 33.31 \\
Pre-fluxing method & $\mathbf{3 2 . 6 2}$ & $\mathbf{3 7 . 6 5}$ & $\mathbf{3 7 . 2 5}$ \\
\hline
\end{tabular}




\section{CONCLUSION}

In this paper, effective methods are simulated and their results are being compared to get the mitigated inrush current. The implementation of controlled switching method is simple which has approximately nullified the inrush current. Controlled switching is easier as compared to Pre-insertion resistor method. Further, it can be seen that, with the application of pre-fluxing technique, the magnitude of inrush current is reduced considerably along with the elimination of DC component. Therefore, the best method for mitigation of inrush current in power transformer is pre-fluxing.

\section{REFERENCES}

[1] M. Steurer and K. Frohlich, "The Impact of Inrush Currents on the Mechanical Stress of High Voltage Power Transformer Coils," IEEE Transactions on Power Delivery, vol. 17, no. 1, pp. 155-160, 2002.

[2] Mudita Banerjee and Anita Khosla, "Comparison and Analysis of Magnetizing Inrush and Fault Condition for Power Transformer," International Journal of Engineering \& Technology (UAE), vol. 7, no. 4-5, pp. 126-129, 2018.

[3] A. Chattopadhyayaa, S. Bandyopadhyayb and S. Chattopadhyay, "Assessment of Discrimination between Inrush Current and Fault Current in a Power Transformer," Canadian Journal on Technology Innovation, vol. 1, pp. 187 -196, 2014

[4] Emir Alibašić, Predrag Marić and Srete Nikolovski, "Transient Phenomena during the Three-Phase 300MVA Transformer Energization on the Transmission Network," International Journal of Electrical and Computer Engineering (IJECE), vol. 6, no. 6, pp. 2499-2505, 2016.

[5] M. Jamali, M. Mirzaie, S. Azghar Gholamian, "Calculation and analysis of transformer inrush current based on parameters of transformer and operating conditions," Electronics and Electrical Engineering, vol. 109, no. 3, pp. 17-20, 2011.

[6] G. B. Kumbhar and S. V. Kulkarni, "Analysis of Sympathetic Inrush Phenomena in Transformers Using Coupled Field-Circuit Approach," 2007 IEEE Power Engineering Society General Meeting, Tampa, FL, pp. 1-6, 2007.

[7] A. Reis, J.C. de Oliveira, R. Apolonio and H. S. Bronzeado, "A controlled switching methodology for transformer inrush current elimination: Theory and experimental validation," 11th International Conference on Electrical Power Quality and Utilisation, Lisbon, pp. 1-6, 2011.

[8] G. Singh and M. Gupta, "Reduction of Harmonics and Inrush Current of Power transformer using Prefluxing Technique," International Journal of Engineering and Technical Research, vol. 3, no. 6, pp. 72-76, 2015.

[9] A. El-Baz and A. I. H. El-Sinnary, "Mitigation methods of magnetizing inrush transient during energization of large power transformer," 2011 IEEE PES Conference on Innovative Smart Grid Technologies-Middle East, Jeddah, pp. 1-6, 2011.

[10] B. Kovan, F. De Leon, D. Czarkowski, Z. Zabar and L. Birenbaum, "Mitigation of inrush currents in network transformers by reducing the residual flux with an ultra-low-frequency power source," in IEEE Transactions on Power Delivery, vol. 26, no. 3, pp. 1563-1570, 2011.

[11] S. J. Asghar, "Elimination of inrush current of transformers and distribution lines," Proceedings of International Conference on Power Electronics, Drives and Energy Systems for Industrial Growth, New Delhi, India, vol. 2, pp. 976-980, 1996.

[12] M. T. Hagh and M. Valizadeh, "Analysis and comparative study of transient inrush current reduction methods," 2007 International Power Engineering Conference (IPEC 2007), Singapore, pp. 287-291, 2007.

[13] X. Guo, H. A. Maier and K. Feser, "A new inrush detection method for transformer differential protection," Archiv für Elektrotechnik, vol. 76, no. 1, pp. 83-91, 1992.

[14] Liana Cipcigan, Wilsun Xu and Venkata Dinavahi, "A new technique to mitigate inrush current caused by transformer energization,” IEEE Power Engineering Society Summer Meeting, Chicago, IL, USA, vol. 1, pp. 570-574, 2002.

[15] D. I. Taylor, J. D. Law, B. K. Johnson and N. Fischer, "Single-phase transformer inrush current reduction using prefluxing," in IEEE Transactions on Power Delivery, vol. 27, no. 1, pp. 245-252, 2012.

[16] WG C., "Controlled switching of unloaded power transformers," Electra, vol. 212, pp. 38-47, 2004.

[17] C. Paul, Y. Ling, and A. Basak, "Investigation of magnetizing inrush current in a single-phase transformer," in IEEE Transactions on Magnetics, vol. 24, no. 6, pp. 3217-3222, 1988.

[18] U Vijay Kumar and S Raghunath Sagar, "Mitigation and Discrimination of Inrush Currents in Three Phase Power Transformer" International Journal for Research in Applied Science \& Engineering Technology, vol. 6, no. 8, pp. $622-628,2018$.

[19] Yu Cui, et al., "A Sequential Phase Energization Technique for Transformer Inrush Current Reduction-Part I: Simulation and Experimental Results," IEEE Power Engineering Society General Meeting, 2004, Denver, CO, vol. 1, pp. 535, 2004.

[20] Wilsun Xu, et al., "A Sequential Phase Energization Technique for Transformer Inrush Current Reduction-Part II: Theoretical Analysis and Design Guide," in IEEE Transactions on Power Delivery, vol. 20, no. 2, pp. 950-957, 2005.

[21] Joydeep Mitra, Xufeng Xu and Mohammed Benidris, "A Controlled Switching Approach to Reduction of Three-Phase Transformer Inrush Currents,” 2018 IEEE Industry Applications Society Annual Meeting (IAS), Portland, OR, pp. 1-7, 2018.

[22] S. G. Abdulsalam, W. Xu, and V. Dinavahi, "Modelling and simulation of three-phase transformers for inrush current studies," in IEE Proceedings-Generation, Transmission and Distribution, vol. 152, no. 3, pp. 328-333, 2005.

[23] J. H. Brunke and K. J. Frohlich, "Elimination of transformer inrush currents by controlled switching. I. Theoretical considerations," in IEEE Transactions on Power Delivery, vol. 16, no. 2, pp. 276-280, 2001.

[24] J. H. Brunke and K. J. Frohlich, "Elimination of transformer inrush currents by controlled switching. II. Application and performance considerations," in IEEE Transactions on Power Delivery, vol. 16, no. 2, pp. 281-285, 2001.

[25] V. O. de Castro Cezar, L. Rouve, J. Coulomb, F. Zgainski, O. Chadebec and B. Caillault, "Elimination of inrush current using a new prefluxing method. Application to a single-phase transformer," 2014 International Conference on Electrical Machines (ICEM), Berlin, pp. 1717-1723, 2014. 


\section{BIOGRAPHIES OF AUTHORS}

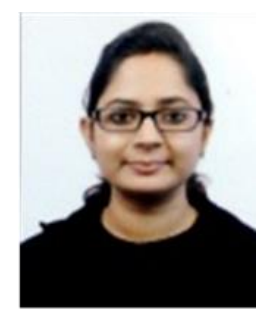

Mudita Banerjee had obtained the B.E. (Electrical) and M.Tech.(Power Electronics and Power System) from Nagpur University, India. Currently, she is pusuing Ph.D. from Manav Rachna International Institute of Research and Studies, Faridabad, India.. She is a Member of the Institution of Engineers (India) and a Life Member of the Indian Society for Technical Education. Her main areas of interest are Network Analysis, Power System Protection and Electrical Machines

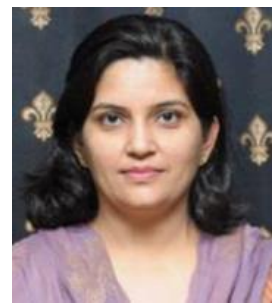

Dr. Anita Khosla is Professor \& Head of Electrical \& Electronics Engineering Department, Manav Rachna International Institute of Research and Studies. She has more than 25 years of teaching experience. She has more than 25 publications in reputed journals \& conferences and 3 books to her credit. She is life time member of ISTE and Institution of Engineers (India). Her main areas of interest are Control System, Power Electronics and Automation. 